\title{
Oceanography
}

CITATION

Hung, C.-C., and G.-C. Gong. 2011. Biogeochemical responses in the southern East China Sea after typhoons. Oceanography 24(4):42-51, http://dx.doi.org/10.5670/oceanog.2011.93.

$\mathrm{DOI}$

http://dx.doi.org/10.5670/oceanog.2011.93

COPYRIGHT

This article has been published in Oceanography, Volume 24, Number 4, a quarterly journal of The Oceanography Society. Copyright 2011 by The Oceanography Society. All rights reserved.

USAGE

Permission is granted to copy this article for use in teaching and research. Republication, systematic reproduction, or collective redistribution of any portion of this article by photocopy machine, reposting, or other means is permitted only with the approval of The Oceanography Society. Send all correspondence to: info@tos.org or The Oceanography Society, PO Box 1931, Rockville, MD 20849-1931, USA. 


\section{BIOGEOCHEMICAL RESPONSES \\ IN THE SOUTHERN EAST CHINA SEA AFTER TYPHOONS}

BY CHIN-CHANG HUNG AND GWO-CHING GONG

ABSTRACT. To understand the biogeochemical impact of typhoons in marginal seas, 16 sea-going expeditions were conducted from 2007 to 2009, covering all four seasons and including periods following the passage of several typhoons in the southern East China Sea (SECS). Higher surface nitrate and chlorophyll $a$

$(\mathrm{Chl} a)$ concentrations were measured in winter and spring, but surface nitrate $(<0.1 \mu \mathrm{M})$ and $\mathrm{Chl} a\left(0.47 \pm 0.17 \mathrm{mg} \mathrm{m}^{-3}\right)$ concentrations were low in summer under nontyphoon conditions. In comparison, elevated surface nitrate $(0.2-2.3 \mu \mathrm{M})$ and $\mathrm{Chl} a$ concentrations $\left(1.11 \pm 0.40 \mathrm{mg} \mathrm{m}^{-3}\right)$ were recorded in the SECS several days after the passage of each of three typhoons in 2008. The results demonstrate that nutrientrich waters are brought to the surface after the passage of typhoons, after which phytoplankton flourish. Most importantly, elevated particulate organic carbon (POC) fluxes (552 $\pm 28 \mathrm{mg} \mathrm{C} \mathrm{m}^{-2} \mathrm{~d}^{-1}$ ) were observed after

Typhoon Jangmi, about a threefold increase from the monthly mean value $\left(184 \pm 37 \mathrm{mg} \mathrm{m}^{-2} \mathrm{~d}^{-1}\right)$. These field investigations demonstrate that typhoons can have a profound effect on nutrient supply, phytoplankton growth, and POC fluxes in marginal seas.

The diatom Chaetoceros sp. is one of the dominant phytoplankton in the southern East China Sea in April and June. 


\section{INTRODUCTION}

Continental margins account for only $8 \%$ of the ocean's surface area, but they contribute approximately $30 \%$ of the global primary production (Liu et al., 2000). Walsh (1989) proposed continental shelf regimes as an important organic carbon source to the open ocean because marginal seas have elevated phytoplankton primary production and higher particulate organic carbon (POC) inventories as compared to the open ocean. Thus, marginal seas are believed to have crucial influence on marine carbon biogeochemical cycling (Liu et al., 2010, and references therein). Indeed, one of the major objectives of the international research project LandOcean Interaction in the Coastal Zone (LOICZ) is to quantify the exchange of carbon among continental shelves, marginal seas, and the open ocean. In addition, the coastal upwelling zones of marginal seas, among the most productive regimes of the marine food chain, contribute significantly to global fishery resources and catches (FAO, 2002).

The East China Sea (ECS) is one of the largest marginal seas in the western Pacific Ocean. The southern East China Sea (SECS), a major ECS fishing ground, is located near the northern tip of Taiwan. Mackerel and swordtip squid are two of the most important fishery resources in the SECS, with a production season from approximately spring to early winter (Sassa et al., 2008; Wang et al., 2008). Elevated phytoplankton biomass on the SECS shelf break has been documented (Gong et al., 1995, 2000; Chen, et al., 2001) and likely provides a good source of food for both adult and larval mackerels (Sassa et al., 2008). Researchers have found recurring upwelling off northeast Taiwan in the SECS (Chern et al., 1990; Liu et al., 1992; Jan et al., 2011, in this issue), and with it, transport of nutrients, mainly from subsurface Kuroshio waters, onto the shelf. However, some reports suggest that phytoplankton production in the ECS is limited in summer due to nitrogen deficiency (Chen et al., 2001; Liu et al., 2010). Satellite-derived average sea surface temperature (SST) in the SECS is about $28^{\circ} \mathrm{C}$ from July to September (Wang et al., 2008), suggesting that SECS surface water is likely nitrate-limited, based on the relationship between nitrate and temperature (Gong et al., 1995). The results of fishing catches (Figure 1) also suggest that nutrient supply may not support high biological productivity in the SECS in summer.

Elevated biogeochemical concentrations (e.g., nutrients, chlorophyll $a$ [Chl $a]$ ) and new and primary production (NP and PP) in the SECS have been reported after an upwelling event (Chen et al., 2001; Gong et al., 2003). Although POC flux out of the euphotic zone is also an important parameter to measure, it has seldom been investigated directly in the SECS. Floating sediment traps, with some possible biases caused by hydrodynamic, particle-solubility, and zooplankton effects (Gardner, 1980; Buesseler et al., 2007), were used to measure POC fluxes at the bottom of the euphotic zone. A gap remained in our understanding of biogeochemical fluxes in the SECS, however, because most of the previously published data, including nutrient, Chl $a$, and PP in the SECS, were collected under good weather conditions (suitable for cruise investigations, roughly defined as wind speed less than $15 \mathrm{~m} \mathrm{~s}^{-1}$ or wave height less than $2 \mathrm{~m}$; Chen, 2000; Chen et al., 2001; Gong et al., 1995, 2000, 2003) and seldom after extreme atmospheric events (such as dust storms and typhoons).

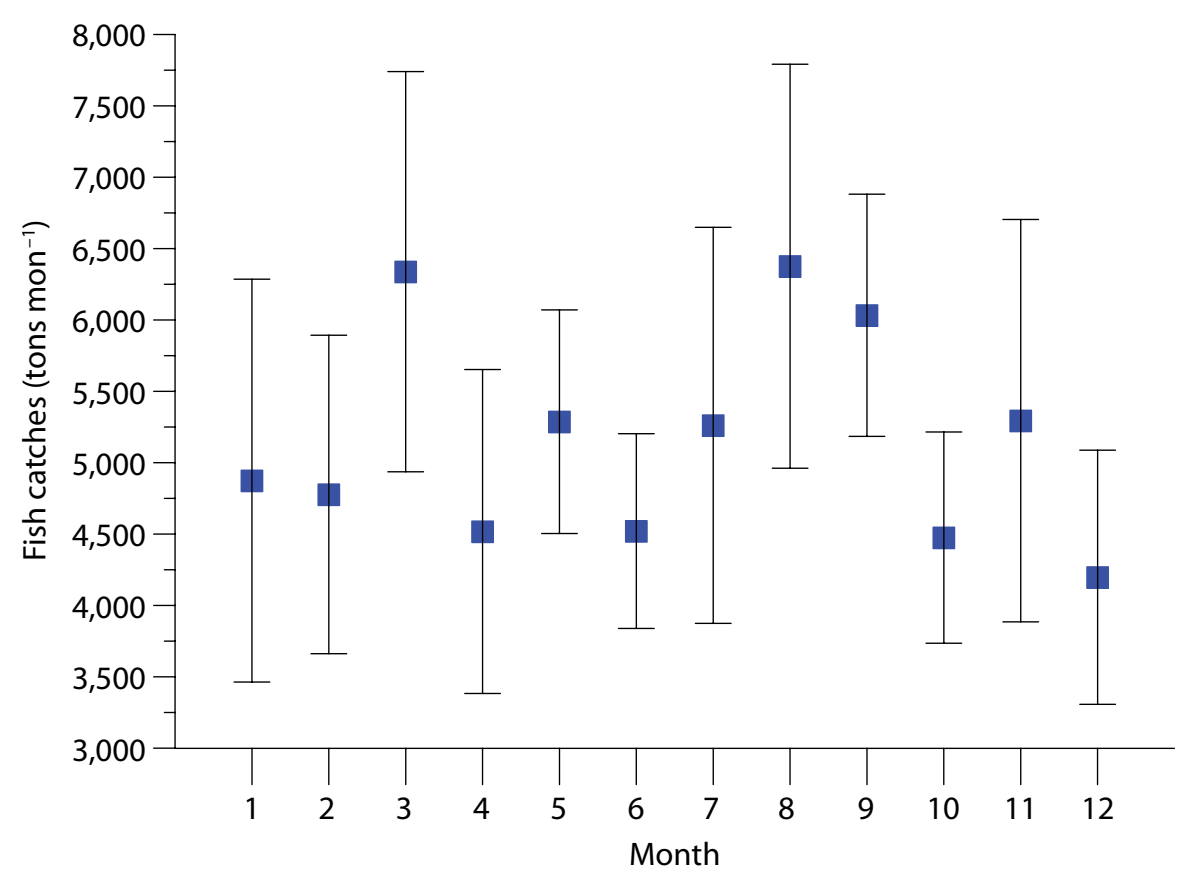

Figure 1. Monthly mackerel catches (nine-year mean, 2001-2009) in the southern East China Sea. From http://www.fa.gov.tw 
Episodic atmospheric events can enhance ocean nutrient supplies, significantly affecting marine biological activity and geochemical cycling (Chang et al., 1996; Shiah et al., 2000; Chen et al., 2003, 2009; Walker et al., 2005, 2006; Zhao et al., 2008; Siswanto et al., 2007, 2008, 2009; Goni et al., 2009; Hung et al., 2009, 2010a; Ren et al., 2011). According to historical typhoon records, eight to ten typhoons pass the Asian continental marginal seas each year (see http://www. cwb.gov.tw). To better understand the biogeochemical impacts of typhoons on marginal seas, we present hydrographic information (e.g., temperature, nitrate concentration, and $\mathrm{Chl} a$ ) and POC flux measurements in the SECS from 2007 to 2009 , covering all four seasons and including periods following the passage of several typhoons (Figure 2, Table 1).

\section{NITRATE SUPPLY AND PHYTO- PLANKTON BIOMASS DURING NONTYPHOON PERIODS}

Under nontyphoon conditions, SST in the SECS shows great seasonal variation, ranging from $18.4^{\circ}$ to $29.0^{\circ} \mathrm{C}$, with

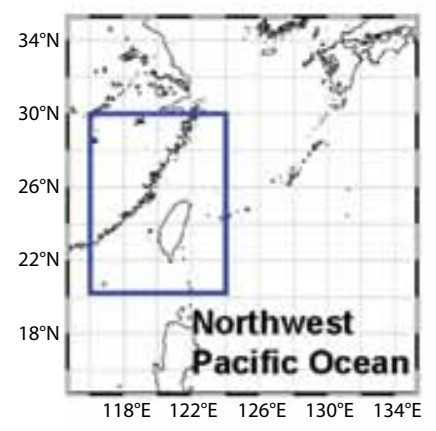

Figure 2. Satellite-observed (using Advanced Very High Resolution Radiometer) sea surface temperature before (left panels) and after (right panels) typhoons in the southern East China Sea. Typhoons include Kalmaegi $(a, b)$, Fungwong (c, d), Sinlaku (e, f), and Jangmi $(g, h)$. Solid lines on panels $b$, $d, f$, and $g$ represent typhoon tracks in the western Pacific Ocean in 2008. Red stars in panels $\mathrm{d}, \mathrm{f}$, and $\mathrm{h}$ represent sediment trap deployment locations.

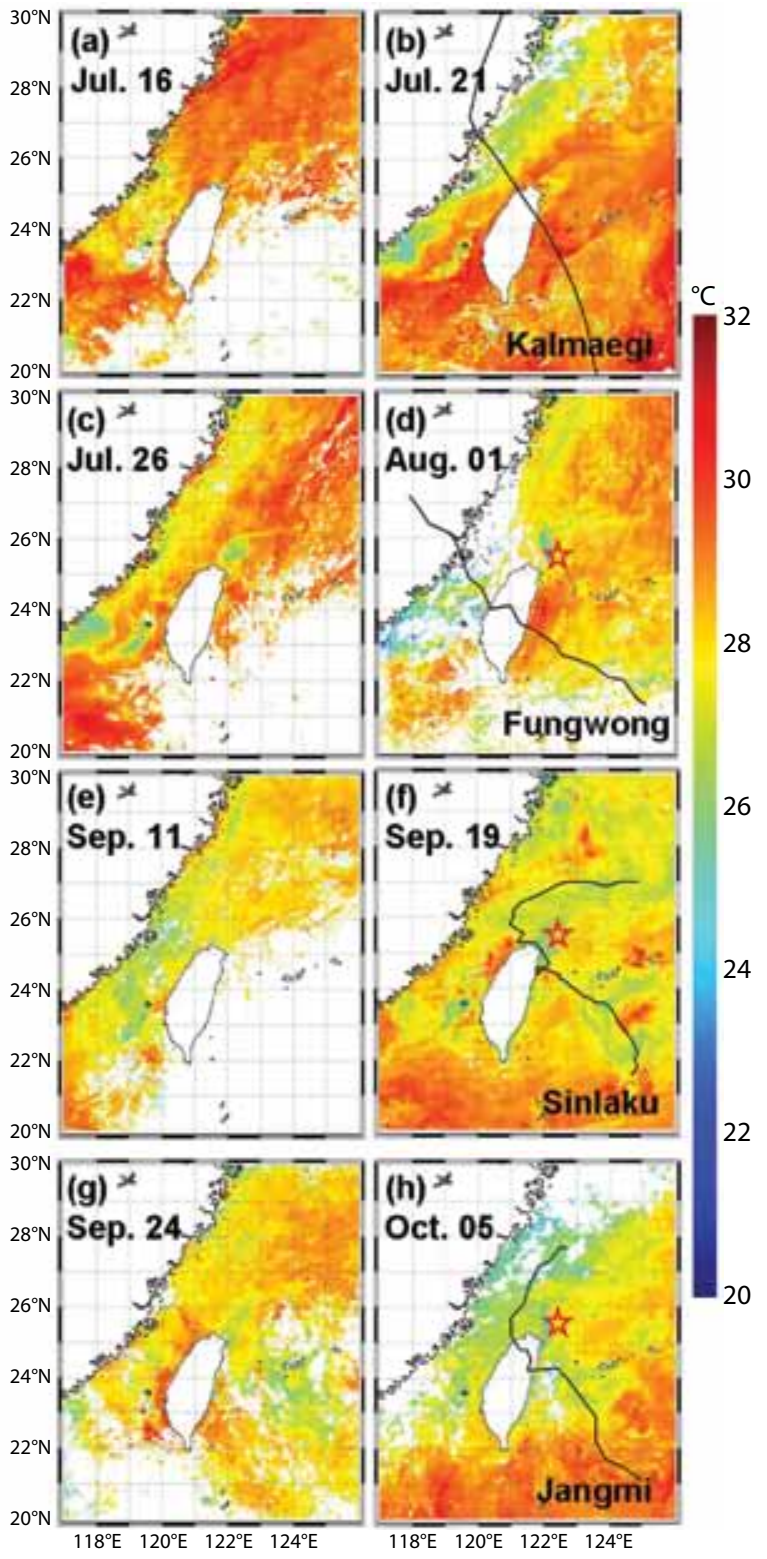

the highest SST in summer, followed by autumn and spring, and the coldest value in January (Figure 3a). Surface nitrate concentrations in the SECS also exhibit significant seasonal variation, ranging from below the detection limit $(\sim 0.1 \mu \mathrm{M})$ to $4.1 \mu \mathrm{M}$, with maximum value in January, median value in spring, and lowest value in summer (Figure 3b). Field surveys from 2007 to 2009 indicate that surface nitrate concentration was below detection levels in the SECS during the summer months when no typhoons occurred (Tables 1 and 2). Previous monthly and intensive investigations show similar values for the seasonal variation of SST and surface nitrate values in the SECS (Gong et al., 1995, 2003; Liu et al., 1992; Chen et al., 2001). Liu et al. (1992) and Gong et al. (1995) reported that the cold, nitrate-rich water brought to the SECS shelf area is mainly from bottom intrusion of Kuroshio water during autumn, winter, and spring. Despite the persistent southwest monsoon during summer over Taiwan Strait (June to September), nitrate-rich upwelled water at the surface has seldom been observed in the SECS (Liu et al., 1992; Gong et al., 1995). Generally, the nitrate inventory in the SECS water column in summer is lower than that in other seasons. For example, the integrated nitrate inventory $\left(\mathrm{I}-\mathrm{NO}_{3}\right)$ down to the bottom of the euphotic zone (defined as $1 \%$ of surface light intensity) in summer ranged from 0.05 to 0.293 (average $=0.161)$ mol- $\mathrm{N} \mathrm{m}^{-2}$ (Table 2). The nitrogen inventories in March 2007, December 2008, and February 2009 were $0.236,0.323$, and 0.444 mol- $\mathrm{N} \mathrm{m}^{-2}$, respectively. These observations suggest that nitrate supply in the whole water column in the SECS in the summer is indeed lower than 
that in other seasons.

According to Gong et al. (1995), the presence of the upwelled Kuroshio subsurface water is a major nutrient source to the SECS shelf. The riverine input of nutrients, which is revealed by the less-saline coastal water with a salinity $<34$, is seldom observed in the mid and outer shelf. Moreover, benthic regeneration of nutrients is unimportant in the shelf region, where the sediments are relic sand and the organic carbon content is very low $(<0.3 \%$; Liu et al., 1992). Furthermore, atmospheric nitrogen (nitrate and ammonium) deposition (including dry and wet deposition

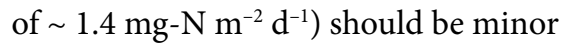
sources as compared to the derived nitrogen flux $\left(31.8 \mathrm{mg}-\mathrm{N} \mathrm{m}^{-2} \mathrm{~d}^{-1}\right)$ measured in the euphotic zone (Table 2; Chen and Chen, 2008; Hung et al., 2009).

Based on field surveys, our current understanding of the summer nutrient supply in the SECS is that it cannot support the high biological activity that Hung et al. (2000) reported ( $\mathrm{PP}=1,000 \mathrm{mg}-\mathrm{C} \mathrm{m}^{-2} \mathrm{~d}^{-1}$ in summer) or that Chen et al. (2001) reported ( $\mathrm{PP}=1,010 \mathrm{mg}-\mathrm{C} \mathrm{m}^{-2} \mathrm{~d}^{-1}$ in summer). These concentrations imply that any combination of regular nitrate upwelled under nontyphoon conditions, atmospheric deposition, and riverine input cannot account for the observed high nitrogen export flux out of the euphotic zone. Other nitrogen sources need to be found to balance the nitrogen budget.

Surface Chl $a$ concentrations varied seasonally (Figure 3c), with higher values $\left(0.7 \sim 1.3 \mathrm{mg} \mathrm{m}^{-3}\right)$ in spring and winter, and lower values $\left(0.24-0.65 \mathrm{mg} \mathrm{m}^{-3}\right)$ in summer under nontyphoon conditions. Chen (2000) reported that the surface Chl $a$ values ranged from 0.71 to $1.51 \mathrm{mg} \mathrm{m}^{-3}$ in a similar area of the SECS in April and June. Gong et al. (2003) conducted four cruises covering four seasons and found that higher surface Chl a concentrations $\left(\sim 1 \mathrm{mg} \mathrm{m}^{-3}\right)$ occur in autumn and winter, and lower surface $\mathrm{Chl} a$ values $\left(\sim 0.3-0.4 \mathrm{mg} \mathrm{m}^{-3}\right)$ in summer. These results demonstrate that our field observations for Chl $a$ distribution patterns during nontyphoon conditions are in

\section{Chin-Chang Hung (cchung@mail.nsysu.edu.tw) is Professor, Institute of Marine Geology and Chemistry, National Sun Yat-sen University, Kaohsiung, Taiwan, and Professor, Institute of Marine Environmental Chemistry and Ecology, National Taiwan Ocean University, Keelung, Taiwan. Gwo-Ching Gong is Distinguished Professor and Director, Institute of Marine Environmental Chemistry and Ecology, Center of Excellence for Marine Bioenvironment and Biotechnology, National Taiwan Ocean University, Keelung, Taiwan.}

Table 1. Sea surface temperature (SST), nitrate concentration, and chlorophyll $a(\mathrm{Chl} a)$ concentration before and after 2008 typhoons. Note: SST and $\mathrm{Chl} a$ data for $25.2^{\circ} \mathrm{N}-25.7^{\circ} \mathrm{N}, 122.1^{\circ} \mathrm{E}-122.6^{\circ} \mathrm{E}$ before typhoon passage were derived using Advanced Very High Resolution Radiometer (AVHRR) infrared sensors and Moderate Resolution Imaging Spectroradiometer (MODIS) ocean color, respectively. Nitrate concentrations before the typhoon were derived by the relationship between nitrate (nitrate = 33-1.25 x SST; Hung et al., 2010a) and SST.

SST, nitrate, and Chl $a$ data were measured in the field shortly after typhoon passage at the trap station located at $25.40^{\circ} \mathrm{N}, 122.45^{\circ} \mathrm{E}$.

\begin{tabular}{|c|c|c|c|c|c|c|c|c|c|c|c|}
\hline \multirow[b]{2}{*}{ Typhoon } & \multicolumn{2}{|c|}{ Wind Speed $\left(\mathrm{m} \mathrm{s}^{-1}\right)$} & \multirow{2}{*}{$\begin{array}{l}\text { Landfall } \\
(\mathrm{mm} / \mathrm{dd}) \\
\end{array}$} & \multirow{2}{*}{$\begin{array}{c}\text { Affecting } \\
\text { Time (days) }\end{array}$} & \multirow{2}{*}{$\begin{array}{l}\text { Cruise } \\
(\mathrm{mm} / \mathrm{dd})\end{array}$} & \multicolumn{2}{|c|}{ SST $\left({ }^{\circ} \mathrm{C}\right)$} & \multicolumn{2}{|c|}{ Nitrate $(\mu \mathrm{M})$} & \multicolumn{2}{|c|}{ Chl $a\left(\mathrm{mg} \mathrm{m}^{-3}\right)$} \\
\hline & Max & Near ECS & & & & Before & After & Before & After & Before & After \\
\hline Fungwong & 43 & 37 & $07 / 28$ & 3 & $07 / 21-07 / 25$ & 28.7 & & $<0.1$ & & na & \\
\hline Fungwong & & & & & $08 / 03$ & & 26.7 & & 0.3 & & 1.45 \\
\hline Sinlaku & 51 & 41 & $09 / 14$ & 5 & $09 / 08-09 / 11$ & 28.0 & & $<0.1$ & & 0.39 & \\
\hline Sinlaku & & & & & 09/19 & & 28.0 & & 0.2 & & 0.85 \\
\hline Sinlaku & & & & & $09 / 21$ & & 27.5 & & 0.3 & & 0.73 \\
\hline Jangmi & 53 & 50 & $09 / 28$ & 3 & $09 / 25-09 / 26$ & 27.5 & & $<0.1$ & & na & \\
\hline Jangmi & & & & & $10 / 03$ & & 24.6 & & 2.3 & & 0.92 \\
\hline Jangmi & & & & & $10 / 06$ & & 24.0 & & 1.9 & & 1.61 \\
\hline
\end{tabular}

Max $=$ Maximum wind speed

$\mathrm{ECS}=$ East China Sea

Affecting Time: Time period in the southern East China Sea affected by typhoons.

Cruise: The field cruise was conducted four to eight days after typhoon landfall.

Some SST and Chl $a$ data before the typhoons were not available (na) due to cloud cover. 
agreement with previous studies, particularly the low Chl $a$ concentrations during summer under good weather conditions.

The seasonal pattern of surface Chl a concentration in the SECS is similar to that of nitrate, suggesting that nitrate supply is directly related to phytoplankton growth (Figure 3c). As mentioned earlier, Kuroshio water intrusion is the major nutrient source for phytoplankton growth in the SECS (Liu et al., 1992; Chen et al., 2001; Jan et al., 2011, in this issue). In summer, the warm, nitrate-depleted Taiwan Strait Water often suppresses upwelling events off northeastern Taiwan, and
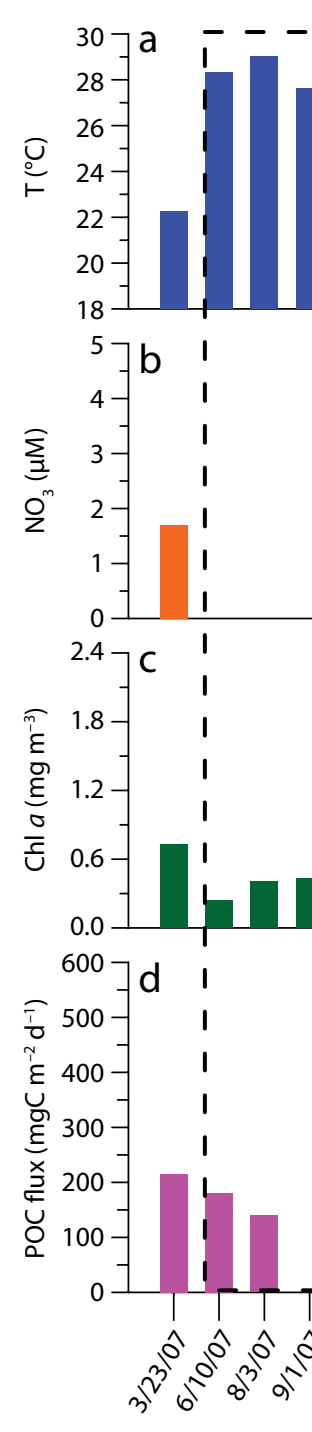

therefore the nutrient-rich cold dome water is hardly observed in the upper

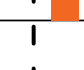
1
1
1

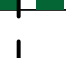 layer (Gong et al., 1995; Wu et al., 2008; Jan et al., 2011, in this issue). Chen (2000) reported that the dominant phytoplankton composition in the SECS in April and June is diatoms (including Nitzschia sp., Thalassionema nitzschi- oides, Chaetoceros sp., Rhizosolenia fragilissima, and Leptocylindrus minimus), dinoflagellates (including Prorocentrum and Protoperidinium), Trichodesmium sp., and coccolitho- phores (Chen, 2000). Recent work of C.C. Chung of the Center for Marine Bioenvironment and Biotechnology,

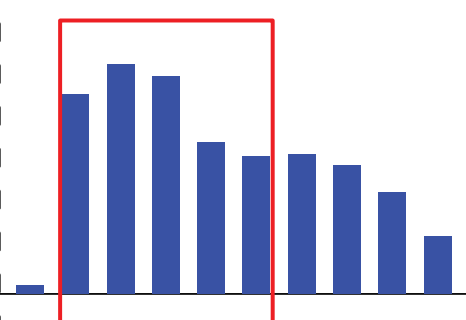 ||

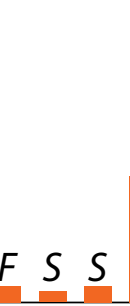

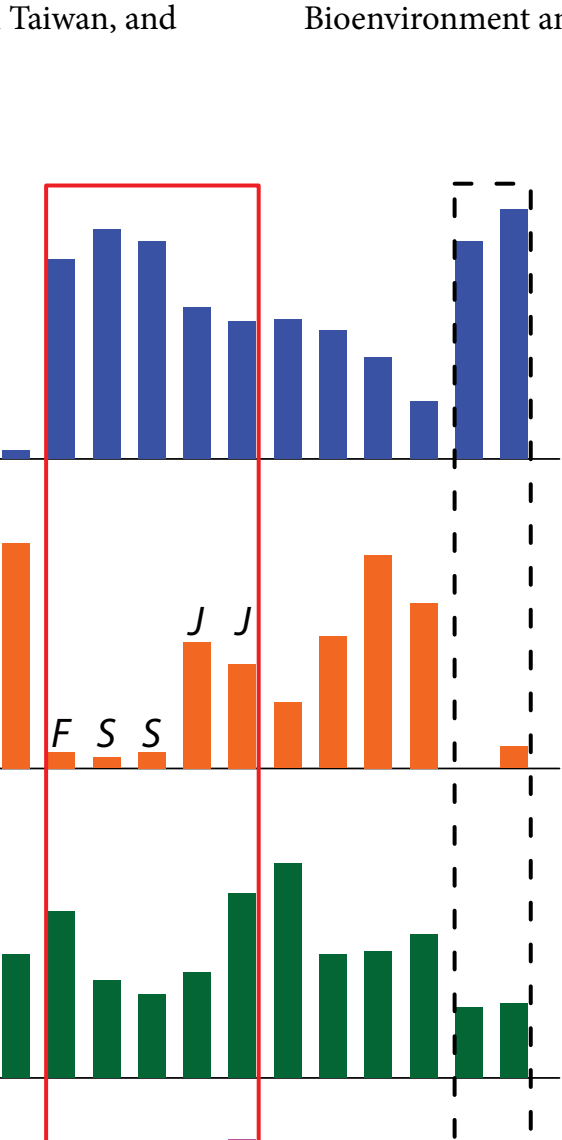
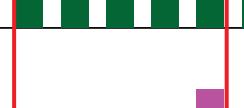
Figure 3. Field-measured (a) sea surface tempera- ture $(T),(b)$ nitrate $\left(\mathrm{NO}_{3}\right),(\mathrm{c})$ chlorophyll a (Chl a) concentrations, and (d) particulate organic carbon (POC) flux in the southern East China Sea under nontyphoon condi- tions (black dashed line boxes) and after typhoon conditions (red box) from 2007 to 2009. Note: There are no surface nitrate concentrations during nontyphoon periods because they fall below the detection $\operatorname{limit}(<0.1 \mu M)$. $\mathrm{F}=$ Typhoon Fungwong. $\mathrm{S}=$ Typhoon Sinlaku. 1 1 1 1 1

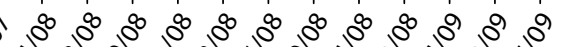

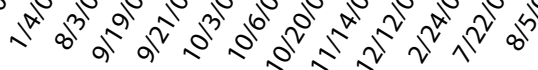
$\mathrm{J}=$ Typhoon Jangmi. 
the POC flux with increasing depth.

However, the increase in POC flux with increasing depth (Hung et al., 2003) suggests that lateral transport of resuspended sediment near the bottom significantly contributed to the measured POC fluxes, resulting in an overestimate of the vertical flux. Chen et al. (2001) reported that new production (down to $0.6 \%$ of surface light intensity) in the SECS was approximately $320 \mathrm{mg}-\mathrm{C} \mathrm{m}^{-2} \mathrm{~d}^{-1}$, and Hung et al. (2000) found that nitrate uptake rate (down to $10 \%$ of surface light intensity) in similar regions (i.e., $25.41^{\circ} \mathrm{N}, 122.35^{\circ} \mathrm{E}$ and $25.34^{\circ} \mathrm{N}$,

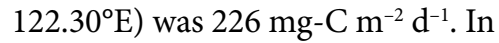
other words, the POC fluxes measured by floating sediment traps are in agreement with those values measured by Chen et al. (2001) and Hung et al. (2000), if analytical uncertainty on both new production and nitrate uptake rate are considered (Chen, 2001).

Because the study area is approximately $70 \mathrm{~km}$ from Taiwan, it could be argued that particle composition has been influenced by bottom resuspension or lateral advection from terrestrial inputs. As mentioned earlier, the bottom sediments in the study area are relic sand with low organic carbon content $(<0.3 \%$; Liu et al., 1992). No large river is located near the study area, so the recent satellite ocean color data likely represent sea surface conditions that are unaffected by the influx of terrestrial materials (Hung et al., 2010a). Consequently, sediment resuspension and lateral particle transport are unlikely to have occurred in the study area (as suggested by Hung et al. [2003], the lateral transport occurred in deep depths).

\section{CHANGES IN WATER-COLUMN} PROPERTIES AFTER TYPHOONS Satellite-derived SSTs and field data used in the present study show cooling after the passage of Typhoons Kalmaegi (no field data), Fungwong, Sinlaku, and Jangmi (Figure 2, Table 2). This cooling phenomenon near the SECS after the

Table 2. Data on mixed layer depth (MLD), euphotic zone (EZ: $1 \%$ of surface light intensity), surface nitrate $\left(\mathrm{NO}_{3}\right)$, surface chlorophyll $(\mathrm{Chl} a)$, integrated nitrate $\left(\mathrm{I}-\mathrm{NO}_{3}\right)$, integrated $\mathrm{Chl} a(\mathrm{I}-\mathrm{Chl} a)$, integrated particulate organic carbon (I-POC), and POC flux in the southern East China Sea, covering four seasons, including periods before and after typhoon events.

\begin{tabular}{|c|c|c|c|c|c|c|c|c|c|}
\hline $\begin{array}{c}\text { Date } \\
(\mathrm{mm} / \mathrm{dd} / \mathrm{yy})\end{array}$ & Typhoon & $\begin{array}{c}\mathrm{MLD} \\
(\mathrm{m})\end{array}$ & $\begin{array}{c}\mathrm{EZ} \\
(\mathrm{m})\end{array}$ & $\begin{array}{c}\mathrm{NO}_{3} \\
(\mu \mathrm{M})\end{array}$ & $\begin{array}{c}\mathrm{I-NO} \\
\left(\mathrm{mol} \mathrm{m}^{-2}\right)\end{array}$ & $\begin{array}{c}\mathrm{Chl} a \\
\left(\mathrm{mg} \mathrm{m}^{-3}\right)\end{array}$ & $\begin{array}{c}\mathrm{I}-\mathrm{Chl} a \\
\left(\mathrm{~g} \mathrm{~m}^{-2}\right)\end{array}$ & $\begin{array}{c}\text { I-POC } \\
\left(\mathrm{g} \mathrm{m}^{-2}\right)\end{array}$ & $\begin{array}{c}\text { POC flux } \\
\left(\mathrm{mg} \mathrm{m}^{-2} \mathrm{~d}^{-1}\right)\end{array}$ \\
\hline $03 / 23 / 07$ & & 35 & $\mathrm{na}$ & 1.7 & 0.236 & 0.73 & 0.041 & 4.59 & $215 \pm 22$ \\
\hline $06 / 10 / 07$ & & 34 & 65 & 0.0 & 0.046 & 0.24 & 0.031 & 3.20 & $180 \pm 10$ \\
\hline $08 / 03 / 07$ & & 28 & 43 & 0.0 & 0.060 & 0.41 & 0.051 & 3.50 & $140 \pm 22$ \\
\hline $09 / 01 / 07$ & & 14 & 38 & 0.0 & 0.293 & 0.43 & 0.039 & 2.71 & $\mathrm{na}$ \\
\hline $01 / 04 / 08$ & & 38 & 53 & 4.1 & 0.384 & 1.08 & 0.053 & 4.90 & $158 \pm 16$ \\
\hline $08 / 03 / 08$ & Fungwong & 45 & 34 & 0.3 & 0.534 & 1.45 & 0.116 & 5.52 & $265 \pm 14$ \\
\hline $09 / 19 / 08$ & Sinlaku & na & 32 & 0.2 & na & 0.85 & na & na & $225 \pm 34$ \\
\hline $09 / 21 / 08$ & Sinlaku & na & 30 & 0.3 & na & 0.73 & na & na & $224 \pm 33$ \\
\hline $10 / 03 / 08$ & Jangmi & na & na & 2.3 & na & 0.92 & na & na & $285 \pm 14$ \\
\hline $10 / 06 / 08$ & Jangmi & na & na & 1.9 & na & 1.61 & na & na & $552 \pm 28$ \\
\hline $10 / 20 / 08$ & & 22 & 44 & 1.2 & 0.272 & 1.87 & 0.120 & 3.46 & $230 \pm 24$ \\
\hline $11 / 14 / 08$ & & 52 & 51 & 2.4 & 0.370 & 1.08 & 0.048 & 4.20 & $141 \pm 15$ \\
\hline $12 / 12 / 08$ & & 51 & 50 & 3.9 & 0.323 & 1.10 & 0.067 & 4.98 & $236 \pm 25$ \\
\hline $02 / 24 / 09$ & & 47 & 51 & 3.0 & 0.444 & 1.25 & 0.058 & 4.70 & $162 \pm 16$ \\
\hline $07 / 22 / 09$ & & 37 & 38 & 0.0 & 0.243 & 0.62 & 0.035 & na & $166 \pm 21$ \\
\hline $08 / 05 / 09$ & & na & na & 0.4 & na & 0.65 & na & na & $215 \pm 23$ \\
\hline
\end{tabular}

$M L D=$ Depth at which density increased by $0.1 \mathrm{~kg} \mathrm{~m}^{-3}$ from the density at the surface.

$\mathrm{I}-\mathrm{NO}_{3}, \mathrm{I}-\mathrm{Chl} a, \mathrm{I}-\mathrm{POC}=$ integrated $\mathrm{NO}_{3}, \mathrm{Chl} a$, and $\mathrm{POC}$ from 0 to $75 \mathrm{~m}$ depth.

$\mathrm{Na}=$ Data not available.

No post-storm field data are available for Typhoon Kalmaegi (mid July 2008). 
passage of a typhoon has been observed frequently (Chang et al., 2008; Tsai et al., 2008; Zhao et al., 2008; Siswanto et al., 2007, 2009; Hung et al., 2010a; Jan et al., 2011 , in this issue).

The greater level of wind mixing associated with Typhoon Jangmi likely increased the mixed layer depth (MLD, defined as the depth at which density increased by $0.1 \mathrm{~kg} \mathrm{~m}^{-3}$ compared with the density at the surface) to an extent greater than that associated with Typhoons Fungwong and Sinlaku (Table 1). Figure 2 shows that SST after passage of Typhoon Jangmi was colder than that after Typhoons Fungwong and Sinlaku. Additionally, the MLD after passage of Typhoon Fungwong (45 m) was deeper than the MLD zone (14-37 m) in summer when no typhoons occur. When nontyphoon conditions were prevalent in summer, the depth of the euphotic zone ranged from 38-65 m (Table 2). However, five to seven days
The shallow EZ after a typhoon may be a good indicator of higher phytoplankton biomass induced by nitrate supply.

\section{ENHANCED BIOGEOCHEMICAL} RESPONSES AFTER TYPHOONS Surface nitrate concentrations in the study area four to seven days after the passage of Typhoons Fungwong, Sinlaku, and Jangmi were $0.3,0.2-0.3$, and 1.9-2.3 $\mu \mathrm{M}$, respectively (Table 1). In comparison, surface nitrate concentrations during summer under pretyphoon conditions were generally below the detection limit (<0.1 $\mu \mathrm{M}$; Table 2$)$, and suggest that surface nitrate concentrations after Typhoons Fungwong and Sinlaku did not increase significantly. This result may be attributed to: (1) quick nutrient consumption by phytoplankton five to seven days after the passage of Typhoons Fungwong and Sinlaku, (2) dilution with ambient nutrientdepleted Kuroshio surface water, or

INTENSIVE FIELD OBSERVATIONS COVERING FOUR SEASONS, INCLUDING PERIODS BEFORE AND SHORTLY AFTER THE PASSAGE OF TYPHOONS, ARE PROVIDING EVIDENCE THAT TYPHOONS INFLUENCE NUTRIENT SUPPLY, PHYTOPLANKTON DYNAMICS, AND CARBON EXPORT IN A CONTINENTAL SHELF BREAK REGION.

after the Fungwong and Sinlaku typhoon events, the euphotic zones (EZ) became shallower, ranging from 30 to $34 \mathrm{~m}$, respectively (Table 2 ), and the depth was only about half that of the mean euphotic zone depth reported by Gong et al. (2000) for this region $(60 \pm 10 \mathrm{~m})$.
(3) mixing with nitrate-depleted water from Taiwan Strait. In an extreme case such as Typhoon Jangmi, the measured surface nitrate concentration under nontyphoon conditions was $0.4 \mu \mathrm{M}$ (on 8/5/09 in Table 2), with pretyphoon derived surface nitrate concentration less than $0.1 \mu \mathrm{M}$ (Table 1), whereas the nitrate concentrations five and eight days after typhoon passage (on October 3 and 6,2008 ) increased five- to sixfold (Table 2). The data collected before and after the typhoon suggest that the strong winds and slow speed of Typhoon Jangmi led to upwelling of cold, nutrient-rich waters (Table 1). Babin et al. (2004) and Zheng and Tang (2007) report similar phenomena caused by typhoons.

In addition to comparing surface nutrient concentrations, the amount of nitrate injected into the euphotic zone can also be compared under nontyphoon and post-typhoon conditions. The average, or integrated, nitrate concentration in the water column (I-NO ${ }_{3}$ in Table 2; 0-75 $\mathrm{m}$ ) in the SECS after Typhoon Fungwong was $7.1 \mu \mathrm{M}$ $\left(=0.534 \mathrm{~mol} \mathrm{~m}{ }^{-2} / 75 \mathrm{~m}\right.$ in Table 2 ; see Hung et al. [2010a] for a detailed nitrate profile), suggesting that the typhoon strongly influenced nitrate supply. However, some typhoons may not cause strong upwelling, as suggested by the SST data, which barely showed a decrease after the passage of Typhoon Sinklaku (Table 1 and Figure 2). This slight cooling could be due to upwelling of Kuroshio subsurface water, accompanied by Kuroshio surface water intrusion onto the continental shelf. Others studies show that upwelling strength after typhoons in the SECS differs greatly depending on typhoon strength, speed, and track; Kuroshio instability; and internal tides (Tsai et al., 2008; Siswanto et al., 2009; Hung et al., 2010a). Indeed, the strong correlation between integrated POC and nitrate concentration in the study area supports that concept (Figure 4). When nitrate supply in the water column reaches a certain threshold, the POC inventory is elevated, 
demonstrating that nitrate is an important source for phytoplankton growth. As mentioned earlier, phytoplankton production in the East China Sea is likely limited by nitrogen in summer (Chen et al., 2001). The data suggest that the nitrate supplied through episodic typhoon events in the SECS contributes to phytoplankton growth, and thus is also important for zooplankton and larval fish.

Surface Chl $a$ concentrations in the study area four to seven days after the passage of typhoons Fungwong, Sinlaku, and Jangmi were 1.45, $0.73-0.85$ and $0.92-1.62 \mathrm{mg} \mathrm{m}^{-3}$, respectively (Table 1 ). The average Chl $a$ under nontyphoon conditions was $0.47 \pm 0.17 \mathrm{mg} \mathrm{m}^{-3}(=[0.24+$ $0.41+0.43+0.62+0.65] / 5 \mathrm{mg} \mathrm{m}^{-3}$; Table 2). The average Chl $a$ concentration after the typhoons was $1.11 \pm 0.40 \mathrm{mg} \mathrm{m}^{-3}(=[1.45+0.73+0.85$ $+0.92+1.62] / 5 \mathrm{mg} \mathrm{m}^{-3}$; Table 1$)$. The elevated Chl $a$ concentrations may be related to nutrient supply in the euphotic zone (Figure 3 and Table 1). Alternately, Babin et al. (2004) propose that the mixing of the subsurface Chl $a$ maximum layer with low-Chl $a$ surface water (e.g., phytoplankton dilution theory) can explain such increased surface phytoplankton biomass.

\section{IMPLICATIONS FOR} POC FLUXES AFTER TYPHOON EVENTS

The biogenic carbon flux to the deep ocean is one of the main factors affecting $\mathrm{CO}_{2}$ partial pressure in the atmosphere. Therefore, the amount of POC flux is crucial for understanding the global carbon cycle and its response to climate change (Emerson et al., 1997). Typhoons have a notable impact on POC flux,

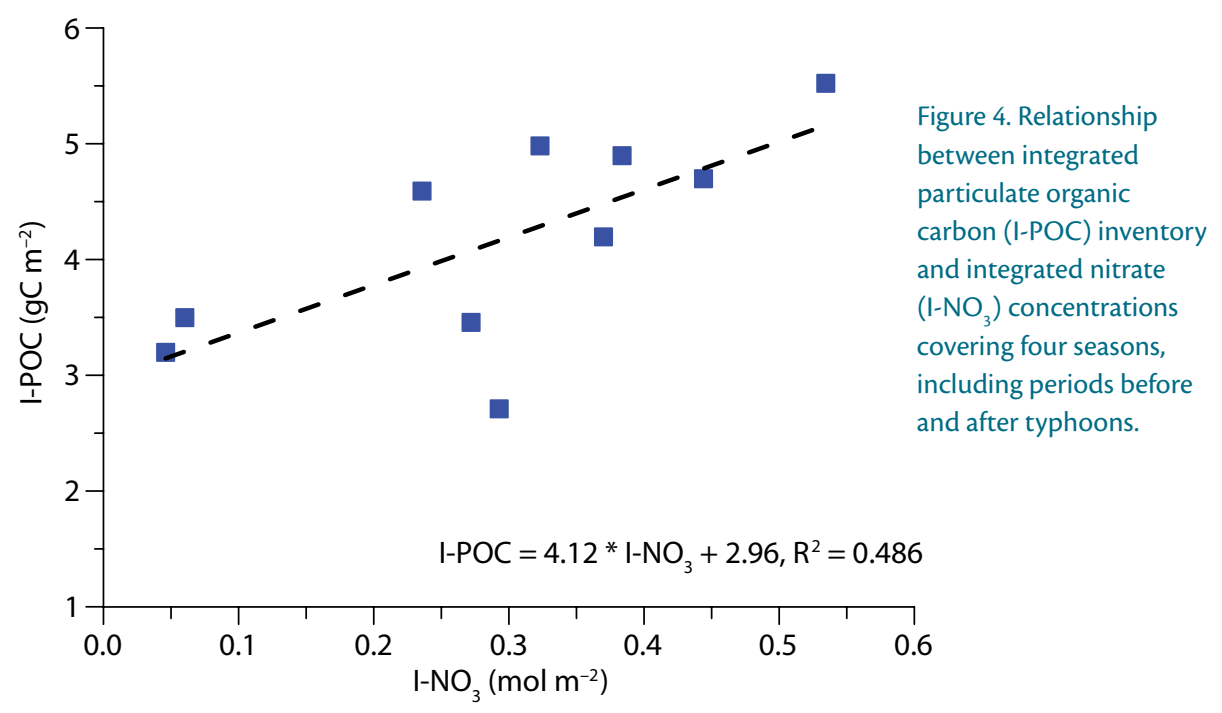

but how important are they to the summer POC flux in the study area? The average areas of the cold-water patch (e.g., $<27^{\circ} \mathrm{C}$ ) in the SECS under nontyphoon and post-typhoon conditions are 2,900 and $10,000 \mathrm{~km}^{2}$, respectively (Hung et al., 2010a). If the POC flux (nontyphoon vs. post-typhoon = 175 vs. $310 \mathrm{mg} \mathrm{m}^{-2} \mathrm{~d}^{-1}$ ) is assumed to be the same in the whole cold-water patch, the nontyphoon and post-typhoon whole

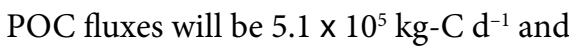
$31 \times 10^{5} \mathrm{~kg}^{-\mathrm{C} \mathrm{d}^{-1}}$ (approximately sixfold higher than nontyphoon conditions), respectively. The result demonstrates that typhoons indeed enhance POC export flux, and the enhanced POC flux can be partially transported out of the euphotic zone. The elevated POC flux after passage of a typhoon might be also caused by changes in the phytoplankton community and the zooplankton grazing effect (i.e., producing more fecal pellets; Figure 5). As mentioned earlier, Chang et al. (1996) reported that major phytoplankton assemblages in the ECS before a typhoon were composed of small phytoplankton, including dinoflagellates and trichodesmium spp., and then changed to pinnate diatoms (e.g., Nitzschia spp. and Thalassionema spp.) and largecell diatoms (Bacteriastrum spp., Chaetoceros spp., and Skeletonema spp.) after the typhoon's passage. Analogous phytoplankton species changes have been reported in the Kuroshio (Chen et al., 2009). In addition to phytoplankton assemblage changes, other factors, such as zooplankton grazing (e.g., enhancing fecal pellets production), aggregation of small particles, and mineral ballast effects, may also be involved in enhancing the biogenic POC flux. Further studies are required to collect vertical profiles of water properties and POC fluxes before and after the passage of a typhoon in other marine environments, including marginal seas and tropical open ocean areas, in order to assess the effects of storm events on global POC export flux.

\section{CONCLUSIONS}

Intensive field observations covering four seasons, including periods before and shortly after the passage of typhoons, are providing evidence that typhoons influence nutrient supply, phytoplankton dynamics, and carbon export in a 

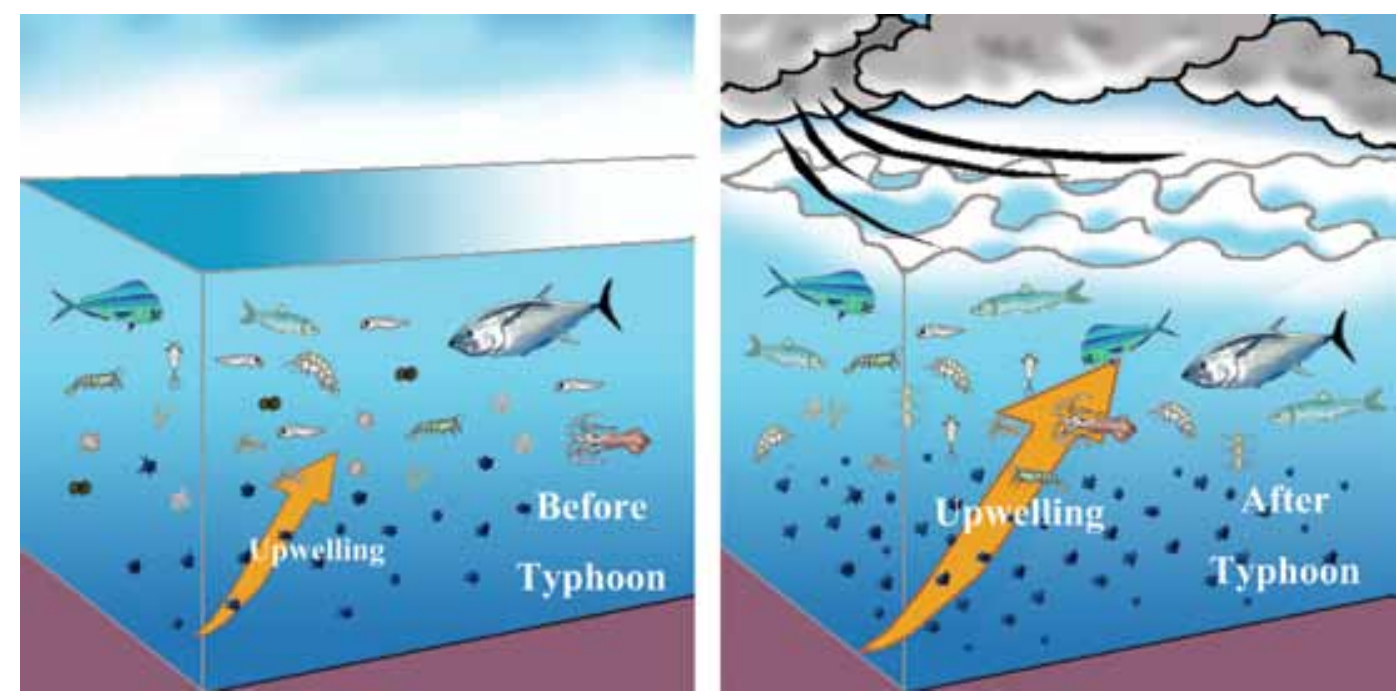

Figure 5. A simple diagram showing enhanced biological responses before and after typhoons in the summer. Left panel: Little cold, nutrient-rich water supports a marine food chain where dinoflagellates and cyanobacteria are the dominant phytoplankton species generating appropriate sinking particles under nontyphoon conditions. Right panel: A robust supply of cold, nutrient-rich water supports a marine food chain where pinnate diatoms and centric diatoms are the dominant phytoplankton species generating elevated sinking particle fluxes after the passage of a typhoon. continental shelf break region. Most importantly, enhanced nutrient supply after the passage of typhoons results in higher biological production, and likely zooplankton production as well. Specific conclusions are: (1) typhoons have an important impact on SST, nitrate, $\operatorname{Chl} a$, and POC flux; (2) both in situ Chl $a$ concentrations and POC fluxes after a typhoon are much greater than those before its passage; and (3) typhoons greatly enhance the export flux of POC out of the euphotic zone rather than enhancing recycling in the surface layer, suggesting that enhancement in biogenic carbon production can be efficiently exported down to deep water by tropical cyclones.

\section{ACKNOWLEDGEMENTS}

We appreciate the assistance of the crew of R/V Ocean Researcher 2, G.-S. Hsieh, J.-M. Wu, L.-C. Wei, C.-C. Chung, and C.W. Tseng. We also thank M.A. Lee and Y. Chang for providing satellite color images before and after typhoons. We acknowledge helpful comments on this paper from two anonymous reviewers and the editor. This research was supported by the National Science Council of Taiwan (NSC99-2628-M-110-001, NSC100-2119-M-110-003, NSC982611-M-019-014-MY3) and the Top University Program.

\section{REFERENCES}

Babin, S.M., J.A. Carton, T.D. Dickey, and J.D. Wiggert. 2004. Satellite evidence of hurricane-induced phytoplankton blooms in an oceanic desert. Journal of Geophysical Research 109, C03043, http://dx.doi.org/ 10.1029/2003JC001938.

Buesseler, K.O., A.N. Antia, M. Chen, S.W. Fowler, W.D. Gardner, O. Gustafsson, K. Harada, A.F. Michaels, M. Rutgers van der Loeff, M. Sarin, and others. 2007. An assessment of the use of sediment traps for estimating upper ocean particle fluxes. Journal of Marine Research 65:345-416.

Chang, J., C.-C. Chung, and G.-C. Gong. 1996. Influences of cyclones on chlorophyll $a$ concentrations and Synechococcus abundance in a subtropical western Pacific coastal ecosystem. Marine Ecology Progress Series 140:199-205, http://dx.doi.org/10.3354/meps140199.

Chang, Y., H.-T. Liao, M.-A. Lee, J.-W. Chan, W.-J. Shieh, K.-T. Lee, G.-H. Wang, and Y.-C. Lan. 2008. Multisatellite observation on upwelling after the passage of Typhoon Hai-Tang in the southern East China Sea. Geophysical Research Letters 35, L03612, http:// dx.doi.org/10.1029/2007GL032858.

Chen, C.T.A., C.T. Liu, W.S. Chuang, Y.J. Yang, F.K. Shiah, T.Y. Tang, and S.W. Chung. 2003. Enhanced buoyancy and hence upwelling of subsurface Kuroshio waters after a typhoon in the southern East China Sea. Journal of Marine Systems 42:65-79, http://dx.doi.org/10.1016/ S0924-7963(03)00065-4.
Chen, H.Y., and L.D. Chen. 2008. The importance of anthropogenic inputs and continental derived dust for the distribution and flux of water-soluble nitrogen and phosphorus species in aerosol within the atmosphere over the East China Sea. Journal of Geophysical Research 113, D11303, http://dx.doi.org/ 10.1029/2007JD009491.

Chen, Y.-L.L. 2000. Comparisons of primary productivity and phytoplankton size structure in the marginal regions of southern East China Sea. Continental Shelf Research 20:437-458, http://dx.doi.org/10.1016/S0278-4343 (99)00080-1.

Chen, Y.-L.L., H.-Y. Chen, W.H. Lee, C.C. Hung, G.T.F. Wong, and J. Kanda. 2001. New production in the East China Sea, comparison between well-mixed winter and stratified summer conditions. Continental Shelf Research 21:751-764, http://dx.doi.org/10.1016/ S0278-4343(00)00108-4.

Chen, Y.-L.L., H.-Y. Chen, S. Jan, and S.-H. Tuo. 2009. Phytoplankton productivity enhancement and assemblage change in the upstream Kuroshio after typhoons. Marine Ecology Progress Series 385:111-126, http://dx.doi.org/ 10.3354/meps08053.

Chern, C.S., J. Wang, and D.P. Wang. 1990. The exchange of Kuroshio and East China Sea shelf water. Journal of Geophysical Research 95:16,017-16,023.

Emerson, S., P. Quay, D. Karl, C. Winn, L. Tupas, and M. Landry. 1997. Experimental determination of the organic carbon flux from openocean surface waters. Nature 389:951-954, http://dx.doi.org/10.1038/40111.

FAO. 2002. The State of World Fisheries and Aquaculture 2002. FAO, Rome, Italy.

Gardner, W.D. 1980. Sediment trap dynamics and calibration, a laboratory evaluation. Journal of Marine Research 38:17-39. 
Gong, G.-C., K.-K. Liu, and S.-C. Pai. 1995. Prediction of nitrate concentration from two end member mixing in the southern East China Sea. Continental Shelf Research 15:827-842, http://dx.doi.org/10.1016/0278-4343 (94)00039-P.

Gong, G.-C., F.-K. Shiah, K.-K. Liu, Y.-H. Wen, and M.-H. Liang. 2000. Spatial and temporal variation of chlorophyll $a$, primary productivity and chemical hydrography in the southern East China Sea. Continental Shelf Research 20:411-436, http://dx.doi.org/10.1016/ S0278-4343(99)00079-5 .

Gong, G.-C., Y.H. Wen, B.W. Wang, and G.J. Liu. 2003. Seasonal variation of chlorophyll $a$ concentration, primary production and environmental conditions in the subtropical East China Sea. Deep-Sea Research Part II 50:1,219-1,236, http://dx.doi.org/ 10.1016/S0967-0645(03)00019-5.

Goni, G., M. Demaria, J. Knaff, C. Sampson, I. Ginis, F. Bringas, A. Mavume, C. Lauer, I.I. Lin, M.M. Ali, and others. 2009. Applications of satellite-derived ocean measurements to tropical cyclone intensity forecasting. Oceanography 22(3):190-197, http://dx.doi.org/ 10.5670/oceanog.2009.78.

Hung, C.-C., G.-C. Gong, W.-C. Chung, W.-T. Kuo, and F.-C. Lin. 2009. Enhancement of particulate organic carbon export flux induced by atmospheric forcing in the subtropical oligotrophic northwest Pacific Ocean. Marine Chemistry 113:19-24, http://dx.doi.org/ 10.1016/j.marchem.2008.11.004.

Hung, C.-C., L. Guo, K. Roberts, and P.H. Santschi. 2004. Upper ocean carbon flux determined by ${ }^{234} \mathrm{Th}$ and sediment traps in the Gulf of Mexico. Geochemical Journal 38:601-611.

Hung, C.-C., and G.-C. Gong. 2007. Export flux of POC in the main stream of the Kuroshio. Geophysical Research Letters 34, L14610, http:// dx.doi.org/10.1029/2007GL030236.

Hung, C.C., L. Guo, G. Schultz, J. Pinckney, and P.H. Santschi. 2003. Production and flux of carbohydrate species in the Gulf of Mexico. Global Biogeochemical Cycles 17, 1055, http:// dx.doi.org/10.1029/2002GB001988.

Hung, C.-C., C. Xu, P.H. Santschi, S.-J. Zhang, K.A. Schwehr, A. Quigg, L. Guo, G.-C. Gong, J.L. Pinckney, R.A. Long, and C.-L. Wei. 2010b. Comparative evaluation of sediment trap and ${ }^{234} \mathrm{Th}$-derived POC fluxes from the upper oligotrophic waters of the Gulf of Mexico and the subtropical northwestern Pacific Ocean. Marine Chemistry 121:132-144, http:// dx.doi.org/10.1016/j.marchem.2010.03.011.

Hung, C.-C., G.-C. Gong, W.-C. Chou, C.-C. Chung, M.-A. Lee, Y. Chang, H.-Y. Chen, S.-J. Huang, Y. Yang, W.-R. Yang, and others. 2010a. The effect of typhoon on particulate organic carbon flux in the southern East China Sea. Biogeosciences 7:3,521-3,550, http://dx.doi. org/10.5194/bg-7-3007-2010.
Hung, C.-C., G.T.F. Wong, K.-K. Liu, F.-K. Shiah, and G.-C. Gong. 2000. The effects of light and nitrate levels on the relationship between nitrate reductase activity and ${ }^{15} \mathrm{NO}_{3}^{-}$uptake: Field observations in the East China Sea. Limnology and Oceanography 45:836-848, http://dx.doi. org/10.4319/lo.2000.45.4.0836.

Hung, J.J., C.S. Lin, Y.C. Chung, G.W. Hung, and W.S. Liu. 2003. Lateral fluxes of biogenic particles through the Mien-Hua canyon in the southern East China Sea slope. Continental Shelf Research 23:935-955, http://dx.doi.org/10.1016/ S0278-4343(03)00085-2.

Jan, S., C.-C. Chen, Y.-L. Tsai, Y.J. Yang, J. Wang, C.-S. Chern, G. Gawarkiewicz, R.-C. Lien, L. Centurioni, and J.-Y. Kuo. 2011. Mean structure and variability of the cold dome northeast of Taiwan. Oceanography 24(4):100-109, http:// dx.doi.org/10.5670/oceanog.2011.98.

Li, S.-L. 2009. Particulate organic carbon flux in the upwelling region off northeastern Taiwan. Thesis, National Taiwan Ocean University, Keelung, Taiwan.

Liu, K.K., G.-C. Gong, S. Lin, C.Y. Wang, C.L. Wei, and S.Y. Chao. 1992. The year-round upwelling at the shelf break near the northern tip of Taiwan as evidenced by chemical hydrography. Terrestrial Atmospheric and Oceanic Sciences 3:243-275.

Liu, K.-K., K. Iseki, and S.Y. Chao. 2000. Continental margin carbon fluxes. Pp. 187-239 in The Changing Ocean Carbon Cycle. R.B. Hanson, ed., IGBP book series, Cambridge University Press.

Liu, K.K., L. Atkinson, R. Quiñones, and L. Talaue-McManus, eds. 2010. Carbon and Nutrient Fluxes in Continental Margins: A Global Synthesis. IGBP Book Series, Springer, Heidelberg, Germany, 744 pp.

Ren, J.-L., G.-L. Zhang, J. Zhang, J.H. Shi, S.M. Liu, F.M. Li, J. Jin, and C.G. Liu. 2011. Distribution of dissolved aluminum in the Southern Yellow Sea: Influences of a dust storm and the spring bloom. Marine Chemistry 125:69-81, http:// dx.doi.org/10.1016/j.marchem.2011.02.004.

Sassa, C., Y. Tsukamoto, K. Nishiuchi, and Y. Konishi. 2008. Spawning ground and larval transport processes of jack mackerel Trachurus japonicas in the shelf-break region of the southern East China Sea. Continental Shelf Research 28:2,574-2,583, http://dx.doi.org/ 10.1016/j.csr.2008.08.002.

Shiah, F.K., S.W. Chung, S.J. Kao, G.-C. Gong, and K.-K. Liu. 2000. Biological and hydrographical responses to tropical cyclones (typhoons) in the continental shelf of the Taiwan Strait. Continental Shelf Research 20:2,029-2,044, http://dx.doi.org/ 10.1016/S0278-4343(00)00055-8.

Siswanto, E., J. Ishizaka, K. Yokouchi, K. Tanaka, and C.K. Tan. 2007. Estimation of interannual and interdecadal variations of typhoon-induced primary production: A case study for the outer shelf of the East China Sea. Geophysical Research Letters, 34, L03604, http://dx.doi.org/ 10.1029/2006GL028368.

Siswanto, E., J. Ishizaka, A. Morimoto, K. Tanaka, K. Okamura, A. Kristijono, and T. Saino. 2008. Ocean physical and biogeochemical responses to the passage of Typhoon Meari in the East China Sea observed from Argo float and multiplatform satellites. Geophysical Research Letters 35, L15604, http://dx.doi.org/ 10.1029/2008GL035040.

Siswanto, E., A. Morimoto, and S. Kojima. 2009. Enhancement of phytoplankton primary productivity in the southern East China Sea following episodic typhoon passage. Geophysical Research Letters 36, L11603, http:// dx.doi.org/10.1029/2009GL037883.

Tsai, Y., C.-S. Chern, and J. Wang. 2008. Typhoon induced upper ocean cooling off northeastern Taiwan. Geophysical Research Letters 35, L14605, http://dx.doi.org/ 10.1029/2008GL034368.

Walker, N.D., A. Haag, S. Balasubramanian, R. Leben, I.V. Heerden, P. Kemp, and H. Mashriqui. 2006. Hurricane prediction: A century of advances. Oceanography 19(2):24-36, http://dx.doi.org/10.5670/oceanog.2006.60.

Walker, N.D., R.R. Leben, and S. Balasubramanian. 2005. Hurricane-forced upwelling and chlorophyll $a$ enhancement within cold-core cyclones in the Gulf of Mexico. Geophysical Research Letters 32, L18610, http://dx.doi.org/ 10.1029/2005GL023716.

Walsh, J.J. 1989. How much shelf production reaches the deep sea? Pp. 175-191 in Productivity of the Ocean: Present and Past. W.H. Berger, V.S. Smetacek, and G. Wefer, eds, Wiley New York.

Wang, K.-Y., C.-H. Liao, and K.-T. Lee. 2008. Population and maturation dynamics of the swordtip squid (Photololigo edulis) in the southern East China Sea. Fisheries Research 90:178-186, http://dx.doi.org/10.1016/ j.fishres.2007.10.015.

Wu, C.-R., H.-F. Lu, and S.-Y. Chao. 2008. A numerical study on the formation of upwelling off northeast Taiwan. Journal of Geophysical Research 113, C08025, http:// dx.doi.org/10.1029/2007JC004697.

Zhao, H., D. Tang, and Y. Wang. 2008. Comparison of phytoplankton blooms triggered by two typhoons with different intensities and translation speeds in the South China Sea. Marine Ecology Progress Series 365:57-65, http://dx.doi. org/10.3354/meps07488.

Zheng, G.M., and D.L. Tang. 2007. Offshore and nearshore chlorophyll increases induced by typhoon winds and subsequent terrestrial rainwater runoff. Marine Ecology Progress Series 333:61-74, http://dx.doi.org/10.3354/ meps333061. 